\title{
Using Teacher Self-assessment and Reflection to Foster Change in the Writing Classroom
}

\author{
Naima Sahli ${ }^{1} \&$ Fawzia Bouhass Benaissi ${ }^{2}$ \\ ${ }^{1 \& 2}$ Department of English, Faculty of Letters, Languages, and Arts, The University of Djillali Liabes, \\ Sidi Bel Abbès, Algeria \\ Correspondence: Naima Sahli, The University of Djillali Liabes, Sidi Bel Abbès, Algeria. \\ E-mail: naima.sahli@univ-tiaret.dz
}

Received: April 11, $2019 \quad$ Accepted: May 23, $2019 \quad$ Online Published: June 1, 2019

doi: 10.23918/ijsses.v5i4p39

\begin{abstract}
By drawing on Chomsky's (2000) theory of I-concept and McNiff's and Whitehead's (2001) concept of reflective practice as an enquiry by the self into the self, this research study aims at investigating the impact of the practitioner researcher self-assessment and reflection on bringing change into teaching academic writing at university. A focus group was held with a group of Master 1 students at the University of Ibn Khaldoun, Tiaret, and a combination of teacher self-assessment checklist and diary writing was used by the practitioner researcher. Findings indicated that change occurred when there was a willingness to question current practices and sought support to promote quality teaching and learning in the writing classroom.
\end{abstract}

Keywords: Academic Writing, Checklist, Criteria, Diary, Practitioner Researcher, Reflection on Action, Self-Assessment, Engaging Students

\section{Introduction}

Teaching the conventions of academic writing at university is regarded as one of the most demanding tasks to be achieved successfully. At this advanced level, practising writing is no longer about setting a task to students in which they are required to express their own ideas. However; writing academically is a multi-faceted realm that covers miscellaneous aspects. To begin with, at the Masters level, dealing with academic writing tasks is based on the students' deep understanding of core concepts in their domain specialty such as the didactics of English as a Foreign Language. Also, this module is an opportunity to equip Masters students with writing techniques such as note-taking, note-making, paraphrasing, and referencing...etc, Finally, it addresses the students' ability to write several genres including field reports and dissertations. As a matter of fact, engaging the students in developing their academic style depends a great deal on the practitioner researcher's self-assessment and reflection on his/her actions inside and outside the classroom. In this prospect, combining self-assessment checklists and diary writing can be an effective procedure to record the teaching-learning process on one hand, and taking the necessary steps to implement the appropriate interventions. Accordingly, the research questions focus on examining the potentials of teacher self-assessment and reflection on promoting positive change in the writing classroom. They also aim at exploring whether they contribute to entitle the students to active roles in their learning. The first main hypothesis is that change would not take place unless the practitioner researcher addresses her practice weaknesses in the writing classroom, and the teacher self-assessment 
and reflection would not be effective only if they consider the students as partners in the process towards change.

\section{Teacher Self-assessment}

Teacher self-assessment is a part of an ongoing process of the teacher's endeavour to evaluate the degree of the effectiveness of one's performance, methods, skills and attitudes for the sake of adjusting them (Schön, 1987, as cited in Airasian and Gullickson, 1994, p. 06). Or to use self-assessment as a means to positively contribute to students' learning (Ross \& Bruce, 2007, p. 147; Ash 2014).

\section{Reflective Practice}

Reflection is a concept that is at the heart of new trends in teaching languages. Recently, there has been a paramount shift from 'methods' and 'external' views of teaching towards approaches that grant supremacy to 'internal voices' or 'bottom up' views, that is to say teachers themselves. Reflection, in this case, functions as tool of understanding one's teaching through active engagement in observing one's performance inside the classroom. The chief aim of this process is the accumulation of data as a part of a self-evaluation scheme to improve one's practice and to develop professionally (Richards, 2009 , p. ix).

Reflective practice is the ability of the teacher to examine three levels of his/her practice namely; the process of teaching inside the classroom, the objectives of teaching methods and techniques, and whether this teaching yields positive learning outcomes or not (Tice, 2004). Reflective practice has also a pivotal role in ensuring the quality of teaching when the practitioner researcher is well-aware of the impact of the following patterns of his/her teaching particularly: meeting the lesson objectives, identifying the successful aspects of the taught lesson and reconsidering any shortcomings to be addressed (Ash, 2014). The practitioner researcher can reflect on his/ her performance through means of writing and keeping a journal in order to evoke further perceptions and understanding of the practitioner's practices (Norton, 2009, p. 220). By doing so, the practitioner recognises how the recorded events in his/her journal come to develop. In addition to that, writing is a means of evoking sound analysis when reflecting on whether any research study fulfilled the needs and the aspirations of the involved participants or not (Goodnough, 2003, as cited in Norton, 2009, p. 220).

The notion of reflection can be initiated by the teacher, but it involves the students as well. This is mainly due to the nature of their relationship as partners who seek improvement and positive change in the educational setting. To become a critically reflective teacher, these guidelines need to be followed (Dewey, 1933, as cited in Bartlett, 1997, p. 207; Tom, 1980, p.94, as quoted in Airasian and Gullickson, 1994, p. 195):

1. Reflection should be on an issue that takes place within the educational setting.

2. The teacher should find a solution to the identified issue.

3. The identified issue should occur during the teacher's practice or performance.

4. The teacher should test any ideas throughout his teaching.

5. Once these ideas are tested, the teacher has to take action to bring about change. 
6. The new action may lead to new understanding, which in turn may provide insights into the teaching process.

\section{The Practitioner Researcher Diary}

Diaries have been used in the educational settings to serve reflection purposes (Engin, 2001). They may be referred to as 'log books' and 'teacher's journal'. Researcher diaries or journals are also important research methods to be used in action research or by teachers conducting their own inquiries (Altrichter, Posch \& Somekh, 2000, p. 11; Burns, 2010, p. 89). A researcher diary is a written device for making notes about the components of any research situation (Koshy, 2005, p. 97). It provides clear accounts of the events, perceptions, behaviours, and discussions that take place in the classroom in the form of thoughts and personal reflections about the evolving nature of the conducted study. The entire process includes designing the research study, data collection and analysis, and writing the research paper (Burns, 1999, p.89, as cited in Bloor \& Wood, 2006, p. 150; Sá, 1996, p. 10). They can also be utilised to record ideas in order to reflect on as a means for identifying new perspectives and directions to be applied in the teaching practice (Richards \& Lockhart, 2009, p. 070).

Research on the use of diaries in the writing classroom tackled several aspects such as the proposed definitions of this device, the evolution of diary use in introspection and retrospection research, and the advantages of such a research method (Bazir, 2016, p. 169). In the same line of thought, the dimension of self-reflection on writing and teacher's feedback were the main theme of several studies. In Klimova's (2015, p. 550) study, the findings suggested that the self-reflective essay had major benefits on the students' learning experience because it gave them the opportunity to have a say about their learning difficulties without any restrictions.

\section{Review of Related Literature}

Teacher self-assessment came into prominence as a distinctive field of research due to the work of Flanders (1963) about Interaction Analysis (Anderson \& Freiberg, 1995, p. 79). In their study, Flanders and Amidon required teachers to examine their recorded teaching sessions by using Flander's Interaction Analysis System (Amidon, Flanders, \& Casper, 1985, as cited in Anderson \& Freiberg, 1995). This system is a means to observe the teacher's and the pupils' verbal interactions and talk only. It consists of 10 activities and behaviours. The first seven levels are meant for teacher's interactions namely; accepting feeling, praise and encouragement, the use of the pupils' ideas, asking questions, lecturing, giving directions, criticising or justifying authority. The remaining three components characterise the pupils' interaction patterns; response, initiation and silence or confusion (Bright, 2015). It is important to highlight the fact that teacher self-assessment serves multiple purposes across disciplines in the existing literature. In this context, teacher self-assessment is reviewed from two distinctive perspectives: the impact of teacher self-assessment on performance and self-assessment in teacher education.

\subsection{Teacher Self-assessment and Effective Practices}

Montgomery and Baker (2007) investigated the writing teacher's self-assessment of their written feedback and compared it with the students' attitudes towards the provided feedback. This study also aimed at identifying whether written feedback catered for the needs L2 writing students. Three main 
themes were highlighted by analysing the questionnaires directed to the teachers and their students and the amount of feedback in the students' portfolios during a whole semester. The first finding indicated that the students admitted that they received a lot of feedback from their writing teachers. However, it seemed that in most cases, feedback was given on local issues (grammar mechanics and spelling) rather than global ones (organisation and content). Secondly, there was a discrepancy in teachers' selfassessment of the provided feedback and the actual feedback provided to the students. This variability raised questions of why some students received more comments than other ones. That means that more research is needed in this area to identify any criteria or explanations for such a discrepancy. The teachers seemed to provide local feedback a lot as opposed to their institution guidelines as a response to their students' needs. Finally, only 2 teachers out of 13 teachers appropriately assessed the kind and the amount of feedback they assigned to their students.

Researchers in vocational education have an interest in teacher self-assessment and its impact on the students. In a study by van Deggelen, den Brok and Beijaard (2012), they examined the relationship between the teachers' evaluation of their coaching competencies and their health students' reflective skills. The sample included 24 teachers from two vocational schools in the Netherlands. These teachers completed 2 self-assessment forms based on criteria and standards, participated in video-taped conversational sessions so as to receive feedback from colleagues within the same study, and submitted written reflective reports. The observation sessions as well as the criteria had a positive impact on the quality of the provided feedback; in most cases, colleagues' feedback was constructive. As far as reflective reports are concerned, the researchers highlighted the fact that the teachers who relied on reflection criteria could write highly structured and detailed accounts of their actions. However, some reports lacked depth and precision because of the absence of any followed criteria.

\subsection{Teacher Self-assessment and Teacher Education}

It is of a paramount importance to review the previous studies about the role of teacher self-assessment and reflection in teacher education programmes so as to gain insight about their impact on the quality of teaching and learning. Shin's study (2006) explored the potentials of combining tutoring and journal writing to advance 12 pre-service teachers' reflection on their actions in an ESL writing class. In this respect, every teacher was asked to tutor one student in writing throughout the whole semester twice a month. Both teachers and their students were from different cultural and linguistic backgrounds. The trainees were exposed to a range of theories, notions and techniques to prepare them for dealing with writing tutoring. The course included notions about teaching the writing skill and writing theories, journal writing, grammar and mechanics in writing, using a written sample to deliver feedback on global and local issues, and finally teaching the student to self-edit and think about their writing in a critical way. By comparing tutoring journals and reflective writing, the researcher identified 5 shared themes among the participants:

1. The advantages of tutoring sessions on pre-service teachers and their students.

2. Developing new teaching styles to respond to the students' needs in writing.

3. Engaging the students in self-correction.

4. What to address first in the students' writing; content or errors?

5. Non-native English language teachers and the establishment of authority as teachers of English. 
The main conclusions highlighted the importance of tutoring and reflection as tools that assisted the preservice teachers in making use of theory and practice in their tutoring and developing their competencies in responding to their students' writing. Eventually, this cross-cultural teaching experience exposed the tutors to recognise and reflect on their roles as teachers of writing in an ESL context. Cheung (2012) also examined whether self-assessment could bring any positive change into an in-service group of student teachers' performance in a multi-lingual context. In this case, 47 female teachers at the Hong Kong Institute of Education took an active part in a self-assessment procedure regarding lesson planning, teaching skills, and reflection. Throughout the study, self-assessment proved to be a tool for learning about one's teaching quality. That means that the in-service teachers focusing on targeted goals made the teachers reflect on their practices and their learners' needs and interests. However, there was a challenging feature for the participants, which is the fact that self-assessment is a demanding and a timeconsuming activity.

Information and Communication Technologies (ICTs) have revolutionised the field of assessment. In their recent research study, Seifert and Feliks (2018) investigated student teachers' opinions about the incorporation of online self- and peer-assessment to enhance the quality of their assessment skills. After the analysis of attitudinal questionnaires and blogs' written accounts, the researchers reported that the students had positive attitudes about self- and peer-assessment, mainly because they were provided with rubrics that made the assessment process fair. By assessing other participants, the students could identify weaknesses in their own writing. In addition, self-assessment encouraged the participants to put additional efforts on the tailoring of their assignments and inspired them to put it into practice with their learners.

Literature about teacher self-assessment and reflection is considerable across disciplines. However; Ross and Bruce (2007) note that the effects of self-assessment are scarcely backed with empirical studies. Moreover, van Deggelen et al (2012, p. 115) conclusively argue that more research is needed in the area of teacher self-assessment and how they are using it to achieve positive learning outcomes. Therefore, this research study extends research on how to use teacher self-assessment in the EFL writing classroom in order to bring change to the teacher's performance and to further the student's engagement.

\section{Method}

To get reliable data about this case, a triangulation method was employed in which the practitioner researcher relied on three data collection methods. The combination of three research tools would contribute to reliability as this study involved participants with equal status in contributing to a profound understanding of the matter in question (Altrichter, Posch, \& Somekh, 2005, p. 115). Thus, the researcher employed three data collection methods: focus group with the students, a self-assessment checklist, and a practitioner researcher diary.

\subsection{Context and Participants}

This study was carried out in the academic year 2018/2019 in the Section of English at the University of Ibn Khaldoun, Tiaret, Algeria. In this study, 02 female teachers participated. The practitioner researcher (Sahli) taught the module of writing techniques and dissertation writing modules for 3 years, in addition 
to supervising Master's students in didactics of EFL and Linguistics. The second teacher is a professor in Applied Linguistics. She is the head of doctoral and Masters' projects. She has a pivotal role in the theoretical underpinnings of this research study. Furthermore, she assumed the responsibility of 'the observer' to address an inconvenience in teacher self-assessment procedures and provided guidelines and support for the practitioner researcher throughout the field study. According to Airasian and Gullickson (1994, pp. 8-9),

This form of assessment is about "self", and teachers' vested interest in the results can cause biased, incomplete, or inadequate descriptions. Teachers' preconceptions and beliefs often preempt careful observation of practice... When the teacher's perception can be supplemented by external perceptions; it is more likely to produce an objective awareness of practice and a more useful self-assessment.

Also, a group of 30 Master students of didactics of EFL were the sample of this study. They were selected on the basis of engaging and enabling them to have an active role in their writing class. Finally, the students have stood as a valuable source of information and feedback for their teacher (Freiberg \& Driscoll, 2005, as cited in Snead \& Freiberg, 2017, p.10).

\subsection{Focus Group}

Striving for change in the writing classroom depends on the partnership between the practitioner researcher and his/ her students. In this respect, the focus group aimed at identifying the needs of the students. Besides, it was used to inform the teacher self-assessment checklist and decisions during a semester of study. At the planning phase, the researchers identified the objectives of the focus group. Its chief objective was to collect information about the students' needs and deficiencies in this module. The questions were open-ended to give the students the opportunity to tackle various dimensions of the themes they might propose.

All the participants studied the module of academic writing for the first time. However; they differed in one important aspect, which is the amount of exposure to the module of research methodology. The significance of this issue lies in the fact that LMD (Licence-Master-Doctorat) students have studied this module for four years so far, but as for the classical system students, their first encounter with it is during their enrolment in Master 1 classes. The sampling of this group was purposive because this type of sampling yields in-depth account of data about the case under investigation. The practitioner researcher started the focus group discussion with a transitional period in which she engaged her students in a small talk about their expectations while studying didactics of English in general. Then she informed them about the aims of this study and the confidentiality of the provided data. These are the posed questions:

1. Would you mention any challenges you have encountered in this module so far?

2. Would you suggest any aspects that you wish to consolidate in this module?

After the analysis of the focus group answers, the researchers identified four shared themes: 
1. Lack of time frame allotted to the module of academic writing.

2. The need to practise writing techniques (notions related to research in EFL and ESL).

3. The level of text complexity, particularly when there are research and methodology-related notions.

4. The need to understand the assessment criteria of their assignments.

The identification of the themes paved the way for the researchers to reflect on these issues by holding a face-to-face conversation. Promoting change and teacher self-assessment cannot function in isolation. That means that there should be an "outside" voice that assists the practitioner researcher. Ross and Bruce (2007, p. 155) referred to the significance of combining self-assessment with other tools:

Without the consistency checks provided by feedback from peers or others, some teachers will generate inflated self-appraisals that reduce motivation to change...Teachers who underrate their performance or who accurately appraise themselves as low performers are also unlikely to change due to the depressing effect of negative self-assessment on teacher efficacy.

Hence, open conversation led to a deep understanding of the challenges of teaching writing and how they have always represented opportunities for the empowerment of teachers to embark in a journey of self-discovery and development. In addition, both teachers discussed how they might contribute to the inclusion of all the student, with different levels and backgrounds. The briefing ended with the following decisions and procedures.

1. The practitioner researcher should explore literature in the field of teacher self-assessment.

2. The results of the focus group would form the basis for the teacher's aim to bring change to her writing class.

3. The four themes (the students' needs and challenges) are considered as a set of goals to be achieved throughout a semester of instruction.

4. The development of a self-assessment checklist and a diary writing form for reflection on action.

\subsection{Teacher Self-assessment and Diary Writing}

The teacher self-assessment checklist incorporates the aspects and the criteria for self-assessment. Besides, the use of the practitioner researcher diary was mainly based on the concept of reflection in teaching that was coined by David Schön in his book the Reflective Practitioner in 1983. In his book, Schön distinguished between two types of reflection; reflection in action and reflection on action. The first one is called "theory-in-use", in which the teacher is able to find solutions to a problem that occurs during teaching by relying on his/her instinct and prior experience. However, reflection on action is done once the action has already taken place. Reflection, in this case, is by means of thinking about the appropriate techniques or strategies that the teacher could have done/ will do to solve a problem during teaching or learning (Bilash, 2011). In this study, reflection on action is the dominant element due to the fact that the researchers met to discuss possible interventions in the writing classroom. The selfassessment checklist was used in the pre- intervention phase. Table 1 shows the teacher self-assessment checklist. 
Table 1: Pre-intervention teacher self-assessment checklist

\begin{tabular}{|c|c|c|c|}
\hline $\begin{array}{l}\text { Aspects of self- } \\
\text { assessment }\end{array}$ & Criteria for self-assessment & yes & no \\
\hline \multirow{10}{*}{$\begin{array}{l}\text { 1.Teacher's } \\
\text { performance }\end{array}$} & 1. I informed my students about the module syllabus & $\sqrt{ }$ & \\
\hline & $\begin{array}{l}\text { 2. I provided my students with a list of module-related } \\
\text { references and peer-reviewed articles }\end{array}$ & $\sqrt{ }$ & \\
\hline & $\begin{array}{l}\text { 3.I ask my students to make some notes before coming to } \\
\text { class }\end{array}$ & $\sqrt{ }$ & \\
\hline & $\begin{array}{l}\text { 4. I remind my students of the short- and long-term } \\
\text { objectives of studying academic writing }\end{array}$ & & \\
\hline & $\begin{array}{l}\text { 5. I rely on lecturing and delivering information in my } \\
\text { teaching }\end{array}$ & $\sqrt{ }$ & \\
\hline & $\begin{array}{l}\text { 6.I engage my students in practical activities on writing } \\
\text { techniques on a regular basis }\end{array}$ & & $\sqrt{ }$ \\
\hline & 7.I encourage my students' inquiry and questions & $\sqrt{ }$ & \\
\hline & 8.I balance my talk time and my students' talk time & & $\sqrt{ }$ \\
\hline & 9.I select artifacts that tackle empirical research in TEFL & $\sqrt{ }$ & \\
\hline & $\begin{array}{l}\text { 10. I take into account my students' prior knowledge in } \\
\text { TEFL and research methodology to a moderate extent }\end{array}$ & $\sqrt{ }$ & \\
\hline \multirow[t]{6}{*}{ 2.Teacher assessment } & 11. I rely on innovative teaching practices like ICTs & & $\sqrt{ }$ \\
\hline & $\begin{array}{l}\text { 12.I seek opportunities to provide my students with } \\
\text { informative constructive feedback during classes }\end{array}$ & $\sqrt{ }$ & \\
\hline & 13. I always check my students' understanding & & $\sqrt{ }$ \\
\hline & $\begin{array}{l}\text { 14.I provide my students with a detailed correction exemplar } \\
\text { of their assignments and official exams }\end{array}$ & $\sqrt{ }$ & \\
\hline & $\begin{array}{l}\text { 15.I use data from my teaching environment to adjust my } \\
\text { teaching }\end{array}$ & & $\sqrt{ }$ \\
\hline & $\begin{array}{l}\text { 16. I perceive other roles of a teacher such as a mentor, a } \\
\text { facilitator, and lifelong teacher. }\end{array}$ & & $\sqrt{ }$ \\
\hline
\end{tabular}

By analysing reflection on actions in diary writing, the researchers identified the themes that corresponded to the themes highlighted in the focus groups. Therefore, they designed an intervention action plan to address these points; the practical side of teaching writing, extending the classical system students' research skills, and fostering formative and self-assessment practices. The action plan consisted of introducing new procedures to the practitioner researcher's lesson planning, engaging the students in taking a more active role in their learning, and using assessment to promote quality teaching and learning.

There was a shift from lecturing and delivering knowledge about academic writing into focusing on the students' practice of writing techniques to develop their academic writing style. For this end, lesson planning revolved around the practical aspects of writing techniques and the involvement of the students in every step of the lesson. These patterns occurred in the writing classroom: 
1. Raising the level of students' participation by activating their prior knowledge.

2. Involving them in discovering how to deal with writing techniques rather than telling them how. (Focus on the process of learning by doing and discovery).

3. Practising writing in class to benefit from the provided feedback to other peers.

4. Learning to negotiate meaning and enriching class discussions about writing as a discipline, not only a module of study.

5. Transferability of some skills to other modules as well.

Time constraints were a significant issue. However, they inspired the researchers to tackle numerous deficiencies in their environment namely; low-resource context with no technological facilities and the students' needs to reinforce their writing and research skills. Thus, Massive Open Online Courses (MOOCs) were used to address the above concerns (for more details about the study, refer to Sahli and Bouhass Benaissi, 2018).

The element of assessment contributed to a new understanding of quality teaching and learning. Although writing assignments were assessed formatively as a part of class learning, they were also used for summative purposes. To function harmonically, formative feedback becomes the norm in the writing classroom. That means that the teacher and the students identified shared points of strengths and demonstrate weaknesses within their assignments. In addition to that, the teacher prescribed tips for improvements and provided them with e-books and pdf documents for further improvement. Furthermore, the practitioner researcher taught her students about meeting her expectations by understanding the importance of quality performance and criteria. Putting these ideas into practice motivated the teacher to develop student self-assessment checklists. In the post-writing phase, the students were required to check whether they applied the criteria for a quality performance or not (Appendix 01). In many sessions, the students developed a sense of awareness about the intended objectives of lessons and how they were related to other notions in academic writing.

\subsection{Data Analysis and Discussion}

The analysis of data sources (the focus group, teacher self-assessment checklist, and the action plan intervention) revealed the trends that led to change in the practitioner researcher's performance and the students' willingness to assume responsibility in their own learning.

\subsubsection{Setting Realistic Goals}

This researcher study provides a broad understanding of the importance of setting goals regarding teacher's performance and the students' needs. In this respect, challenging our own attitudes and practices to embrace change is a highly demanding aim in the educational field. However, it may occur gradually if significant contextual factors take place. In this study, there was a broader vision of goals that transcended the curriculum objectives. That means that the practitioner researcher had a responsive attitude towards her students' needs, which encouraged her to take action towards change. Accordingly, this action plan revolved around realistic achievable goals. Therefore; this study confirms the findings of previous research (i.e., Schunk, 1981), in which he argues that if the teacher sets realistic achievable goals and makes en extra effort, he/she is likely to realise them. In addition to that, Ross and Bruce (2007, p. 148) emphasise the fact that teacher's practices are highly influenced by goal setting and 
efforts; teachers who experiment with innovative methods and are motivated to face difficulties in their teaching are more likely to entrench these new practices in their teaching routine.

\subsubsection{New Roles Leading to New Visions}

The analysis of the teaching situation before the action plan intervention indicated that the dominant mode of teaching was a teacher-centered one due to the fact that imparting knowledge and lecturing were the norm in the writing classroom. However; assuming new roles for the practitioner research and her students was gradually taking place. The core element in this case was admitting one's weaknesses in practice and seeking help and constructive feedback. Therefore; the findings of this study significantly showed that reflection on given aspects such as (methods of teaching, roles of the teacher and the students, and the humane characteristics of teaching) and cooperation with experienced practitioners led to new perceptions. This finding goes hand in hand with the assumption of Boud, Keogh and Walker (1985). They report that developing a repertoire of reflective skills requires a great deal of assistance and support throughout the process of learning how to use information to adjust teaching.

The action plan intervention contributed to a shift from a teacher-centered into a learner-centered classroom, in which the focus is no longer on the teacher herself, but rather on the students and the process of acquiring writing techniques, skills, developing an awareness of quality learning, and being autonomous in virtual learning environments. Throughout the study, the practitioner researcher came to develop humane qualities and visions such as caring for all of the students with different proficiency levels and finding solutions to address their needs and interests. These qualities are essential in inspiring the new generation to show more engagement and commitment to study academic writing. In particular, being able to develop new personality assets in the language classroom proved to be amongst the characteristics of the 'ideal' teacher in a study by Bouhass Benaissi (2015, p.154), in which English language Master students admit that a teacher who cares, understands and tolerates their learning difficulties, and provides help is their most preferable one. In addition to that, these qualities boost their performance in the language classroom.

\subsubsection{The Impact of Criteria in Assessment}

The third trend is the inclusion of criteria in teacher self-assessment and the student self-assessment. By relying on clear criteria to guide the practitioner researcher's new instructional practices, patterns of change started to occur and judgments about the quality of teaching were made in the writing classroom. In addition, communicating the standards and the criteria of a quality performance contributed to the students' understanding of the module requirements, the teacher's expectations and the needed efforts to bridge the gap between their actual performance and the desired goals. It is important to point at the fact that using student self-assessment checklists is a beneficial choice in the writing classroom since it responds to what Sadler (1989, p. 126-127) refers to as a transition from feedback to self-monitoring. That means that the students should be informed about what constitutes quality performance, then they are provided with descriptive artifacts or exemplars that showcase a given level of quality.

In general, this study extended research on the significance of practitioner researcher's constant selfassessment and reflection in making a change in the writing classroom. Developing positive attitudes 
towards criticising our own practice and seeking professional advice are the keys to a journey of facing our anxieties and deficiencies as teachers of a foreign language on one hand, and self-wonderers who challenge themselves to find answers to unquestioned assumptions about their teaching practices. Moreover; raising questions about whether we are making any differences in our teaching environments inspires us to invest time and effort in order to improve our students' achievement and lifelong learning.

\section{Recommendations and Further Implications}

Teachers and students should explore the potentials of engaging in self-assessment and reflective practice. To promote reflection, the following guidelines should be implemented across disciplines.

\subsection{The Practitioner Researcher Continuous Self-development}

The willingness of the practitioner researcher to pursue enquiry and researcher in his classroom is a key for successful reflective practice (Campbell and Norton, 2007, pp. 160-161). . In this prospect, teachers are encouraged to nourish the ability to reflect on their methods of teaching writing and their students' writing as well (reflection in pre-writing stage, while-writing, and post-writing). Hence, reflectionboosting activities can be incorporated in traditional classrooms in order to infuse positive change since research studies showed their effectiveness in doing so. These activities comprise reading case studies, conducting self-studies, keeping journals, recording audio- and video- performances in classrooms, and analysing lessons (Jaeger, 2013, p. 91).

In this regard, these activities support the teacher's engagement with his own experimentation with reflection. Therefore, he identifies the factors that facilitate or hinder the attainment of a set of objectives. Moreover, he highlights the themes and patterns of his own performance that he may need to address. Thus, the teacher is in a constant readiness to analyse and understand himself and his surroundings. According to McDonough and McDonough (1997, p. 125), "the most commonly reported procedure for analysis is a very simple one, consisting of reading and re-reading the text to allow significant themes to become gradually foregrounded". By doing so, it is easier to make the appropriate decisions for the sake of adjusting his teaching and ensuring greater engagement from the part of the students. Once the teacher reinforces his reflection skills, he should engage his students in reflecting about their learning as well. Reflection transcends the classroom setting and inspires the students to pursue lifelong learning, which is the ultimate objective of university instruction.

\subsection{Nurturing Students' Reflection}

The engagement of the students in the process of reflecting on their own learning and taking the appropriate measures to adjust it is of a paramount importance. This process of self-regulation is called 'metalearning' (Watkins, 2010). Reflection cannot stand in isolation without the activation of other supporting elements. To be challenged and engaged at the same time, the students need to be well-aware of their current level, in particular their strengths and weaknesses. In addition, reflection is fostered when it is tied to a clear understanding of the learning process and the material to be learnt. Therefore, developing the students' ability to reflect throughout their journey of learning equips them with the capacity to assess the suitability of their strategies and skills. Then they keep utilising effective ones and experimenting with new ones to achieve the intended learning objectives. If this change happens, it 
means that the student moves from the tacit-learner zone to the reflective-learner zone. If the students are trained on reflection, they do not take things for granted, however, they develop a sense of reflection on the process of their thinking and learning to learn (McDonough \& McDonough, 1997, p. 125). To help the students develop the competency of learning to learn, they are required to nurture the following habits and strategies (Watkins, 2010):

1. The learner should be well-aware of how he approaches learning and whether his learning is effective.

2. The learner can highlight learning difficulties and he can eliminate them.

3. The learner is able to question assumptions.

4. The learner is resilient and committed to finish challenging tasks successfully.

5. The learner can effectively organise his own learning.

6. The learner is well-aware of the need to ask for the teacher's help when he is stuck or when learning resources are limited.

7. The learner can invest in his mistakes and errors by learning how to cope with them in future learning situations.

8. The learner has the ability to develop new learning strategies.

Finally, these qualities function effectively when they are intertwined with the student's conception of the characteristics of an excellent task or the standards of a quality performance (O'Sullivan, 2018, pp.35-36).

\subsection{Fostering Reflection in Teacher Education}

The shift from theory into practice in teaching is not smooth as some pre-service teachers think. In this regard, they may face what is called 'practice shock' in which there is no link between the teacher education programmes and the realities of the educational field. The University of Utrecht introduced a practical initiative in which teacher's reflection, his emotions and needs are at the centre of teacher's education (Korthagen, 2014, p. 4). Reflection, in this case, should not be limited to action only, but also to meaning. That means that the teacher should not reflect on his teaching to take action solely, however, the teacher needs to consider the phase of awareness of essential aspects to bridge the gap between looking back at action and creating alternative to current practice (Korthagen, 1985).

\section{Conclusion}

Effective teaching is driven by an ongoing learning and experimenting with new methods. Both processes entail the practitioner researcher's engagement in self-assessment and reflection in order to refine one's practice and to guarantee the students' active involvement. Our research study attempted to raise questions about the practitioner's current practices and whether there was any room for improvement in teaching academic writing through self-assessment, reflection on action and addressing students' needs. Throughout the process of shifting from teacher-centered teaching into involving the students to assume responsibility in their own learning, gradual improvement became the norm at the level of meeting the students' needs and having new roles for the practitioner researcher, particularly a mentor and a facilitator. 


\section{References}

Airasian, P.W., \& Gullickson, A. (1994). Teacher self-assessment: Potential and Barriers. Kappa Delta Pi Record, 31, 1, 6-10. DOI:10.1080/00228958.1994.10531885.

Airasian, P.W., \& Gullickson, A. (1994). Examination of teacher self-assessment. Journal of Personnel Evaluation in Education, 8, 195-203.

Altrichter, H., Posch, P., \& Somekh, B. (2005). Teachers investigate their work: An introduction to the methodology of action research. London: Routledge.

Anderson, J. B., \& Freiberg, H. J. (1995). Using self-assessment as a reflective tool to enhance the student teaching experience. Teacher Education Quarterly, 22 (1), 77-92.

Ash, A. (2014). Basics to CPD: Reflection. Retrieved on May 28 $8^{\text {th }}, 2018$ at 23: 10 from http: // www. Teachingenglish.org.uk/ blogs/anthony-ash/basics -cpd-reflection

Bartlett, L. (1997). Teacher development through reflective teaching. In J.C. Richards \& D. Nunan (Eds.), Second language teacher education, $7^{\text {th }}$ ed (pp.202-214). Cambridge: Cambridge University Press.

Bazir, A. H. (2016). The role of writing diary in a classroom. JIEB, 4, 41-46.

Beck, R.J., Livne, N. L., \& Bear, S. L. (2007). Teachers' self-assessment of the effects of formative and summative electronic portfolios on professional development. European Journal of Teacher Education, 28, (3), 221-244. DOI: 10.1080/02619760500268733.

Bilash, O. (2011). Reflection in the language classroom. Retrieved on May $28^{\text {th }}, 2018$ at 23:05.from http:// www. sites.educ .ualberta. ca /staff/olenka.bilash/Best\%20of\%Bilash/reflection.html

Burns, A. (2010). Doing action research in English language teaching: A guide for practitioners. New York: Routledge.

Bloor, M., \& Wood, F. (2006). Keywords in qualitative methods: A vocabulary of research concepts. London: SAGE Publications Ltd.

Boud, D., Keogh, R., \& Walker, D. (1985). Promoting reflection in learning: A model in reflection. In D. Boud, R. Keogh, \& D. Walker (Eds.), Turning experience into learning (pp.18-40). London: Kogan \& Page.

Bouhass Benaissi, F (2015). The teacher is a person: Professional qualifications and personal qualities. International Journal of Humanities and Cultural Studies, 1(4), 149-158.

Bright, M. (2015). FIACS: Flanders' interaction analysis category system. Retrieved on March $12^{\text {th }}, 2019$ at 20:15 from http:// http://brightpalliport.blogspot.com

Campbell, A., \& Norton, L. (2007). Learning, teaching and assessing in higher education: Developing reflective practice. Exeter: Learning Matters Ltd.

Cheung, R. H. P. (2012). The use of self-assessment to foster students' learning in teacher education: An experience in teaching practice. Action in Teacher Education, 31, (1), 49-57. DOI: 10.1080/ 01626620.2009 .10463510$.

Chomsky, N. (2000). New horizons in the study of language and mind. Cambridge: Cambridge University Press.

Engin, M. (2001). Research diary: A tool for scaffolding. International Journal of Qualitative Methods, 10 (3), 296-306. DOI: 10.1177/160940691101000308.

Jaeger, E. L. (2013). Teacher reflection: Supports, barriers, and results. Issues in Teacher Education, 22 (1), 89-104.

Klimova, B. (2015). Diary writing as a tool for students' self-reflection and teachers' feedback in the course of academic writing. The $7^{\text {th }}$ World Conference on Educational Sciences (WCES2015), Athens, Greece, 5-7 February 2015, Elsevier Ltd.

Korthagen, F.A.J. (1985). Reflective teaching and pre-service teacher education in the Netherlands. Journal of Teachers Education, 9 (3), 317-326. 
Korthagen, F.A.J. (2014). Promoting core reflection in teacher education: Deepening professional growth. In: L. Orland-Barak \& C.J. Craig (Eds.), International Teacher Education: Promising pedagogies (Part A), 73-89.

Koshy, V. (2005). Action research for improving practice: A practical guide. London: Paul Chapman Publishing.

McDonough, J \& McDonough, S. (1997). Research methods for English language teachers. London: Arnold.

McNiff, J \& Whitehead, J. (2001). Action research: Principles and practice, $2^{\text {nd }}$ ed. London: RoutledgeFalmer.

Montgomery, J.L., \& Baker, W. (2007). Teacher-written feedback: Student perceptions, teacher selfassessment, and actual teacher performance. Journal of Second Language Writing, 16, 82-99. DOI: 10.1016/jsw.2007.04.002.

Norton, L. (2009). Action research in teaching and learning: A practical guide to conducting pedagogical research in universities. Oxon: Routledge.

O'Sullivan, M. (2018). Developing the Cambridge learner attributes. Cambridge: UCLES.

Richards, J.C., \& Lockhart, C. (2009). Reflective teaching in second language classrooms, $17^{\text {th }}$ ed. Cambridge: Cambridge University Press.

Ross, J.A., \& Bruce, C.D. (2007). Teacher self-assessment: A mechanism for facilitating professional growth. Teaching and Teacher Education, 23,146-159. DOI: 10.1016/j.tate.2006.04.035.

Sá, J. (1996). Diary writing: A research method of teaching and learning. The Conference of Science Education: Research Practices, Portugal, the University of Evora.

Sadler, R. (1989). Formative assessment and the design of instructional systems. Instructional Science, $18,119-144$.

Sahli, N., \& Bouhass Benaissi, F. (2018). Integrating Massive Open Online Courses in Teaching Research and Writing Skills. International Journal of Social Sciences \& Educational Studies, 5(2), 231-240.

Schunk, D.H. (1981). Modelling and attributional effects on children's achievement: A self-efficacy analysis. Journal of Educational Psychology, 73(1), 93-105.

Seifert, T., \& Feliks, O. (2018). Online self-assessment and peer-assessment as a tool to enhance student-teachers' assessment skills. Assessment and Evaluation in Higher Education, 1-17. DOI:10.1080/02602938.2018.1487023.

Shin, S.J. (2006). Learning to teach writing through tutoring and journal writing. Teachers and Teaching: Theory and Practice, 12 (3), 325-345.

Snead, L. O., \& Freiberg, H. J. (2017). Rethinking student teacher feedback: Using a self-assessment resource with student teachers. Journal of Teacher Education, 01-14. DOI: $10.1177 / 0022487117734$.

Tice, J. (2004). Reflective teaching: Exploring our own classroom practice. Retrieved on May $8^{\text {th }}, 2018$ at 23:01 from http://www.teachigenglish.org.uk/article/reflective-teaching-exploring-our-ownclassroom-practice.

Van Deggelen, M., den Brok, P., \& Beijaard, D. (2012). Teachers' use of a self-assessment procedure: The role of criteria, standards, feedback and reflection. Teachers and Teaching: Theory and Practice, 19 (2), 115-134. DOI: 10.1080/13540602.2013.741834.

Watkins, C. (2010). Learning, performance, and improvement. Research Matters, 34. 


\section{Appendix 1}

Checklist of a TEFL Research Abstract

While drafting your abstract, pay attention to the following criteria about a well-written abstract

Informant's details

1. I am

Female

Male

2. Age

$$
\text { years old }
$$

\section{Checklist of core components}

3. My abstract contains all the essential components (backgrounds, aims, procedures, findings, and (recommendations).

Yes

No

4. My abstract contains about 250-300 words.

Yes

No

5. The main key words are contained in the title and after the abstract.

Yes

No

6. I mentioned 5 keywords at least.

Yes

No

7. I have fully spelled any abbreviations and acronyms.

Yes

No

8. I used sentences/ expressions that signal every part of the abstract.

Yes

No

9. I provided complete sentences, full words (no contraction), and used the appropriate tenses.

Yes

No 